\title{
THE SOURCE OF GASTRIC LYSOZYME ${ }^{1}$
}

\section{BY SEYMOUR J. GRAY, ROBERT W. REIFENSTEIN,2 J. C. GORDON YOUNG, HOWARD M. SPIRO, AND EDWARD P. CONNOLLY}

\author{
(From the Medical Clinic, Peter Bent Brigham Hospital, the West Roxbury Veterans Ad- \\ ministration Hospital, and the Department of Medicine and the Biophysical \\ Laboratory, Harvard Medical School, Boston)
}

(Submitted for publication August 5, 1950; accepted, September 18, 1950)

Lysozyme is a mucolytic enzyme which has been demonstrated in gastric juice and in the mucosa of the gastric fundus, antrum, pylorus, and duodenum, as well as in other tissues. A role for this enzyme in the pathogenesis of peptic ulcer has been postulated (1).

Investigations in our laboratory indicated that the lysozyme content of the gastric juice of patients with peptic ulcer did not differ from the normal. An increase in lysozyme was found, however, in the tissue at the margin of active gastric ulcers, and the titer appeared to parallel the course and activity of the disease process (2).

The purpose of this communication is to present evidence that the surface epithelial cells are the source of gastric lysozyme. An opportunity to study the role of the surface epithelial cells and the mucoid cells of the gastric glands in lysozyme formation was offered by the work of Glass (3) who presented evidence that the dissolved mucin of human gastric juice was composed of two distinct components with different physical and chemical characteristics-1) dissolved gastric mucoprotein which was produced by the mucoid cells of the gastric glands of the body and fundus, and 2) dissolved gastric mucoproteose which was derived from the digestion of the mucoid of the gastric surface epithelial cells (Figure 1).

The lysozyme content of the gastric juice and the mucoprotein and mucoproteose fractions were measured before and after histamine stimulation in normal subjects and patients with peptic ulcer. Since the mucoprotein fraction may have its origin in the gastric gland and the mucoproteose fraction in the surface epithelial cells, the relationship be-

1 This work was supported in part by grants from the United States Atomic Energy Commission and the $\mathrm{Na}$ tional Institutes of Health.

2 This work was done during the tenure of a Postdoctorate Research Fellowship from the U. S. Public Health Service. tween the individual mucus fractions and the lysozyme titer was determined to evaluate the source of lysozyme formation.

The role of the parietal cells in lysozyme production was studied further by histamine and insulin stimulation of the gastric gland and by measuring the lysozyme content of the gastric juice of patients with pernicious anemia who have diffuse atrophy of the parietal and peptic cells.

\section{METHODS}

Gastric juice was aspirated from 12 normal individuals, 14 patients with gastric ulcer, and 11 patients with active duodenal ulcer after a 12 to 15 hour period of fasting, and three consecutive 15 minute samples were collected with constant suction for 45 minutes. Histamine diphosphate $(0.036 \mathrm{mgm}$. of histamine base per $10 \mathrm{Kg}$. body weight) or insulin (Squibb-20 units intravenously) were administered and fractional samples obtained at $15 \mathrm{~min}$ ute intervals for the subsequent 60 to 160 minutes. All samples were stored in an ice bath to insure minimal loss of enzymatic activity.

The samples were analyzed for lysozyme activity, pep-

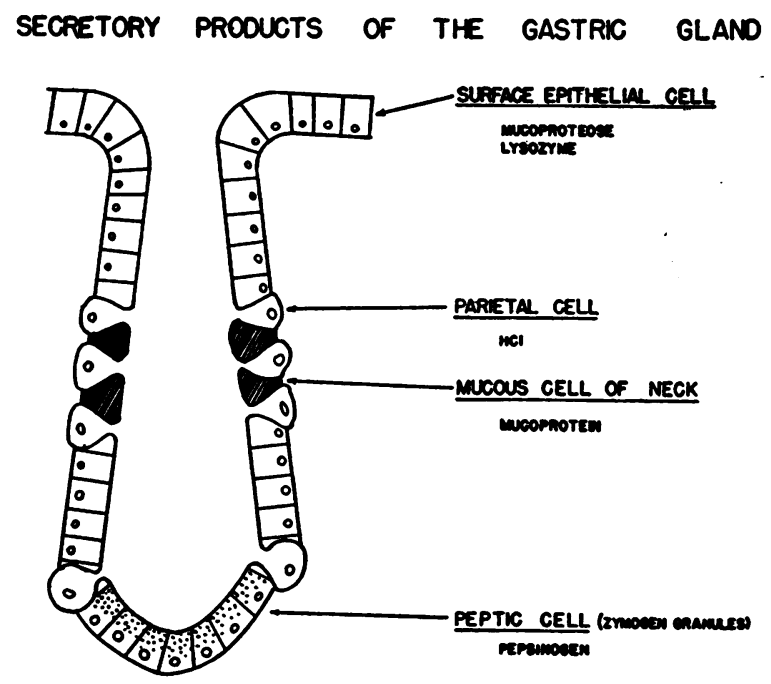

Fig. 1. Schematic Drawing of a Gastric Gland (Adapted from Babkin, (1950) 


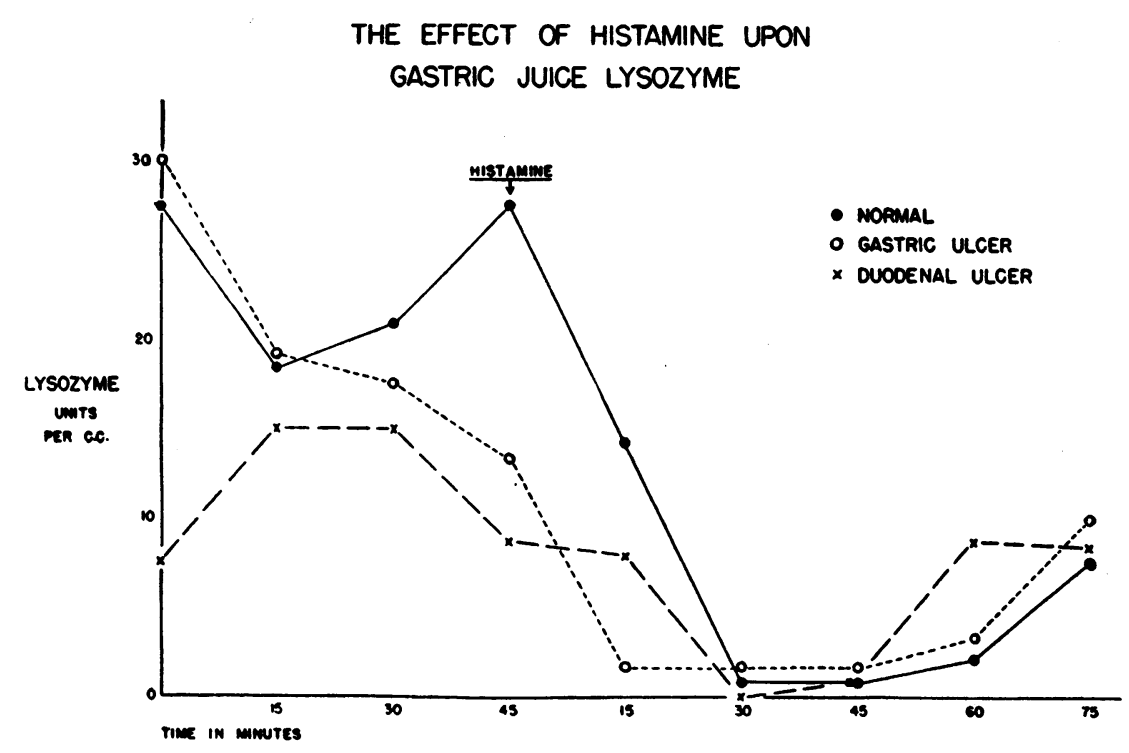

FIG. 2

sin, mucoproteose, and mucoprotein concentration, and the volume, $\mathrm{pH}$, and free and total acid were measured. The lysozyme and pepsin determinations were performed upon filtered gastric juice. The mucoproteose and mucoprotein fractions were measured in the supernatant fluid following centrifugation of the gastric juice.

Lysozyme activity was determined according to Meyer's viscosimetric method employing a mucopolysaccharide substrate obtained from the Micrococcus lysodeikticus (4). Results were expressed in terms of units per cc., where one unit represented that amount of enzyme which, when present at 37 degrees centigrade at a $\mathrm{pH}$ of 5.3 , caused a fall in the relative viscosity of $0.4 \%$ solution of the substrate to half viscosity in ten minutes (4).

Gastric juice pepsin was measured by Bucher's modification of the Anson-Mirsky method employing hemoglobin as a substrate (5). Pepsin concentration was expressed in units per cc.

The analyses for mucoproteose and mucoprotein were carried out as recently outlined by Glass (3), and the results were expressed in terms of mgm. per $100 \mathrm{cc}$.

A Beckman glass electrode $\mathrm{pH}$ meter was used to de- termine $\mathrm{pH}$, and the free and total acid were measured by titration against one-tenth normal sodium hydroxide using Topfer's reagent and phenolphthalein respectively as indicators.

\section{RESULTS}

\section{Effect of Histamine Upon Gastric Lysozyme}

A profound fall in the gastric juice lysozyme occurred within 15 to 20 minutes of histamine stimulation. The lysozyme titer remained depressed for 30 to 45 minutes during the posthistamine period and gradually returned to the pre-histamine level (Figure 2). A simultaneous increase in acidity and volume of secretion was observed in all cases.

The decrease in gastric juice lysozyme following histamine stimulation was not the result of dilution but represented a true decline, since there was a fall in both lysozyme concentration

TABLE I

Effect of histamine upon the lysozyme concentration and total output in the gastric juice

\begin{tabular}{|c|c|c|c|c|c|c|}
\hline & \multicolumn{2}{|c|}{$\begin{array}{c}\text { Mean lysozyme concentration } \\
\text { (units per cc.) }\end{array}$} & \multicolumn{2}{|c|}{$\begin{array}{l}\text { Mean total lysozyme output } \\
\text { per } 15 \text { minute period } \\
\text { (units) }\end{array}$} & \multicolumn{2}{|c|}{$\begin{array}{l}\text { Mean volume output } \\
\text { per } 15 \text { minute period } \\
(c c .)\end{array}$} \\
\hline & Pre-histamine & Post-histamine & Pre-histamine & Post-histamine & Pre-histamine & Post-histamine \\
\hline Normal & 17.2 & 0.9 & 589.9 & 45.2 & 34.3 & 50.3 \\
\hline $\begin{array}{l}\text { Gastric ulcer } \\
14 \text { cases }\end{array}$ & 16.8 & 1.0 & 609.8 & 55.5 & 36.3 & 55.5 \\
\hline $\begin{array}{l}\text { Duodenal ulcer } \\
11 \text { cases }\end{array}$ & 9.8 & 0.8 & 390.0 & 59.4 & 39.8 & 74.3 \\
\hline
\end{tabular}


per cc. of gastric juice and total lysozyme output per unit of time for each 15 minute period of aspiration (Table I). The mean total lysozyme output decreased from levels of 390-589.9 units before histamine stimulation to 45.2-59.4 units in the post-histamine period in normal subjects as well as patients with peptic ulcer (Table I).

High degrees of gastric acidity (below $\mathrm{pH}$ 1.5) inactivated gastric lysozyme. However, when the $\mathrm{pH}$ of the gastric juice exceeded 1.5, there did not appear to be any relationship between $\mathrm{pH}$ and lysozyme concentration.

\section{Effect of Insulin Upon Gastric Lysozyme}

Insulin stimulation was followed by an increase in acidity, pepsin, and volume of secretion and a decrease in gastric lysozyme similar in degree to that observed following histamine administration. The lysozyme titer fell to low levels within 30 to 45 minutes following the intravenous injection of 20 units of insulin and remained depressed for periods of 90 to 150 minutes, gradually returning to the pre-insulin level (Figure 3).

As with histamine, the decrease in gastric juice lysozyme following insulin administration did not
TABLE II

Effect of insulin upon lysoryme concentration and total output in the gastric juice

\begin{tabular}{l|l|c|c}
\hline \hline & & $\begin{array}{c}\text { Pre- } \\
\text { insulin }\end{array}$ & $\begin{array}{c}\text { Post- } \\
\text { insulin }\end{array}$ \\
\hline $\begin{array}{l}\text { Mean lysozyme } \\
\text { concentration } \\
\text { (units per cc.) }\end{array}$ & Normal & 15.2 & 0.37 \\
$\begin{array}{l}\text { Mean total lysozyme } \\
\text { output per 15 minute } \\
\text { period (units) }\end{array}$ & Duodenal ulcer & 19.9 & 0.58 \\
$\begin{array}{l}\text { Mean volume output } \\
\text { per 15 minute period } \\
\text { (cc.) }\end{array}$ & Dormal & 499.9 & 24.2 \\
& Duodenal ulcer & 756.2 & 28.2 \\
\end{tabular}

reflect a dilution phenomenon. A significant decrease was observed in the total output of lysozyme for each fractional 15 minute period of gastric aspiration following the intravenous administration of insulin (Table II).

\section{Mucoprotein and Mucoproteose}

The administration of histamine resulted in a marked increase in the mucoprotein fraction, both in the normal subjects and patients with gastric ulcer, from original mean levels of 30.1 and 11.7 mgm. per $100 \mathrm{cc}$. to mean concentrations of 89.2

\section{THE EFFECT OF INSULIN UPON GASTRIC JUICE LYSOZYME}

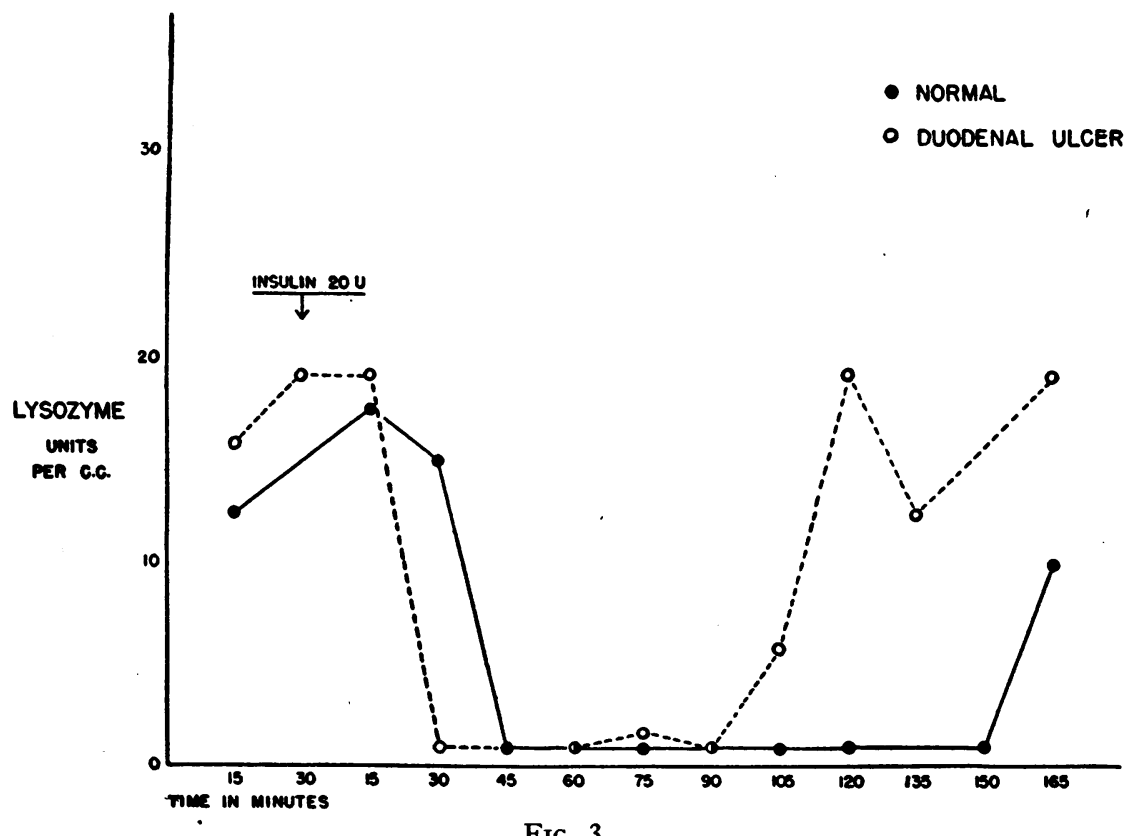

FIG. 3 
TABLE III

Mucus fractions of the gastric juice before and after histamine stimulation

\begin{tabular}{l|r|r|r|r}
\hline \hline & \multicolumn{2}{|c|}{ Normal } & \multicolumn{2}{|c}{ Gastric ulcer } \\
\cline { 2 - 5 } & $\begin{array}{c}\text { Pre- } \\
\text { histamine }\end{array}$ & $\begin{array}{c}\text { Post- } \\
\text { histamine }\end{array}$ & $\begin{array}{c}\text { Pre- } \\
\text { histamine }\end{array}$ & $\begin{array}{c}\text { Post- } \\
\text { histamine }\end{array}$ \\
\hline $\begin{array}{c}\text { Mean mucoproteose } \\
(m g m . \text { per 100 cc.) }\end{array}$ & 155.9 & 44.5 & 168.4 & 57.7 \\
$\begin{array}{c}\text { Mean mucoprotein } \\
(m g m . \text { per 100 cc.) }\end{array}$ & 30.1 & 89.2 & 11.7 & 50.8 \\
$\begin{array}{c}\text { Total soluble gastric } \\
\text { mucin }\end{array}$ & 186.0 & 133.7 & 180.1 & 108.5 \\
$(m g m$. per 100 cc.) & & & & \\
\hline
\end{tabular}

and $50.8 \mathrm{mgm}$. per $100 \mathrm{cc}$., an increase of 196$334 \%$ (Table III).

This pronounced increase in the mucoprotein fraction following histamine stimulation was associated with a proportionate fall in the mucoproteose fraction from mean values of 155.9-168.4 mgm. per $100 \mathrm{cc}$. to mean concentrations of 44.5$57.7 \mathrm{mgm}$. per $100 \mathrm{cc}$. after histamine stimulation (Table III).

A similar increase in the mucoprotein fraction associated with a diminution in the gastric juice

\section{RELATIONSHIP OF LYSOZYME TO MUCOPROTEOSE}

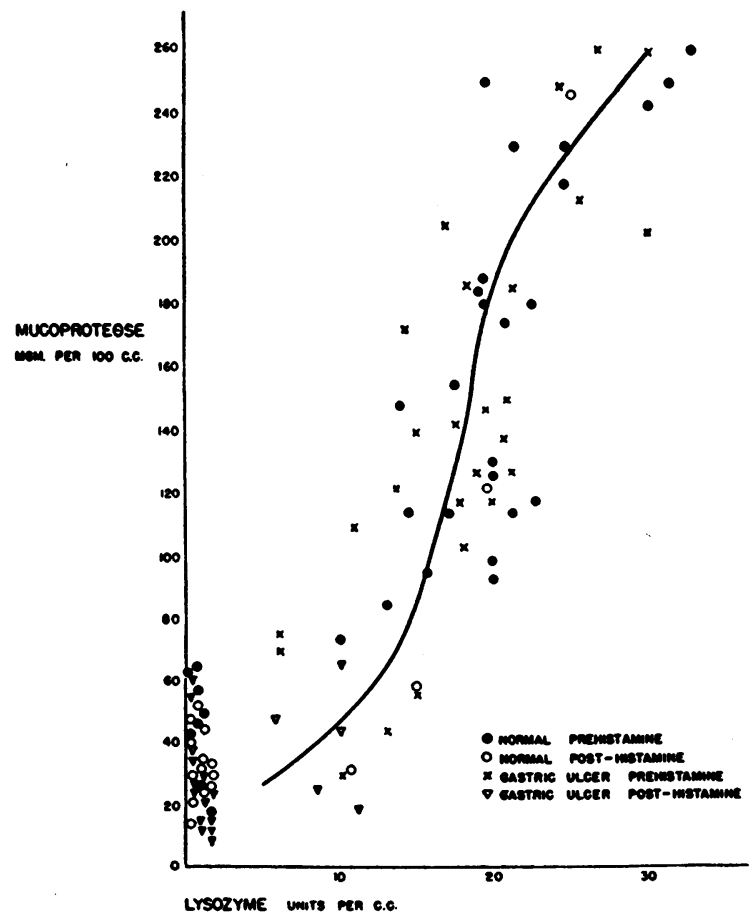

FIG. 4

\section{RELATIONSHIP OF LYSOZYME TO MUCOPROTEIN}

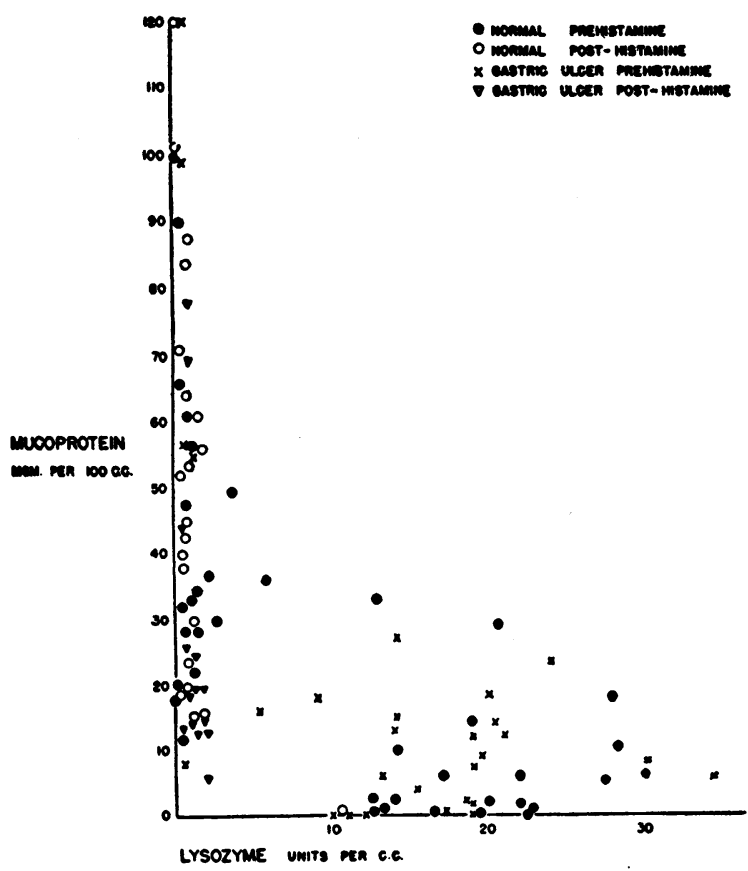

Fig. 5

mucoproteose was observed following the intravenous administration of insulin to normal subjects and patients with peptic ulcer.

\section{Relationship of Lysozyme to Mucus Fractions}

There appeared to be a direct relationship between the concentration of the mucoproteose fraction in the gastric juice and the lysozyme titer (Figure 4). High mucoproteose concentrations were associated with increased lysozyme titers and low mucoproteose levels were observed quite uniformly with diminished lysozyme titers. These findings appeared consistently in normal subjects and patients with gastric ulcer both before and after histamine stimulation.

On the other hand, the gastric juice lysozyme varied inversely with the mucoprotein fraction (Figure 5). Lysozyme levels exceeding 10 units per cc. were accompanied by low mucoprotein concentrations while low lysozyme concentrations were most commonly associated with an elevated mucoprotein fraction. The low lysozyme readings (less than 2 units per cc.) observed in Figure 5 with decreased mucoprotein fractions represent falsely low lysozyme determinations resulting from 
the inactivation of lysozyme by highly acid gastric juice ( $\mathrm{pH}$ below 1.5).

\section{Pernicious Anemia}

The gastric juice of seven patients with pernicious anemia contained normal amounts of lysozyme ( 3.3 to 15.3 units per cc.) and moderately elevated mucoproteose fractions with a mean of $226 \mathrm{mgm}$. per $100 \mathrm{cc}$. which was higher than that observed in normal subjects and patients with gastric ulcer. The mucoprotein fraction, moreover, was definitely diminished below the normal range and was absent in two of the four patients studied (Table IV).

TABLE IV

Gastric juice lysozyme and mucus fractions in patients with pernicious anemia

\begin{tabular}{l|c|c|c|c|c}
\hline \hline Patient & $\begin{array}{c}\text { Lysozyme } \\
\text { titer } \\
\text { (units per } \\
\text { cc.) }\end{array}$ & $\begin{array}{c}\text { Mucoproteose } \\
\text { (mgm. per } \\
100 \text { cc.) }\end{array}$ & $\begin{array}{c}\text { Mucoprotein } \\
\text { (mgm. per } \\
100 \text { cc.) }\end{array}$ & pH & $\begin{array}{c}\text { Volume } \\
\text { of gastric } \\
\text { juice } \\
(c c .)\end{array}$ \\
\hline P. O. & 12.2 & 242.5 & 0.4 & 7.0 & 18 \\
C. U. & 8.4 & 187.5 & 0 & 7.2 & 20 \\
S. M. & 11.2 & 286.5 & 0.8 & 6.2 & 30 \\
H. C. & 5.4 & 187.5 & 0 & 6.8 & 25 \\
E. P. & 3.3 & & & 7.0 & 15 \\
P. Y. & 15.3 & & & 7.0 & 14 \\
B. E. & 4.1 & & & 7.0 & 14 \\
\hline
\end{tabular}

\section{COM MENT}

The decrease in gastric juice lysozyme following histamine and insulin stimulation appears to exclude the parietal cell as a source of gastric lysozyme. The marked decrease in lysozyme could not be attributed to dilution in view of the pronounced fall in total lysozyme output in each 15 minute period. Although some inactivation of lysozyme occurs in highly acid gastric juice, there was no significant inactivation when the $\mathrm{pH}$ was greater than 1.5. In the majority of studies, particularly in normal subjects and gastric ulcer patients, the $\mathrm{pH}$ was above the range where lysozyme inactivation may take place. It would be unlikely, moreover, for a cell to produce both an enzyme and the hydrochloric acid which could inactivate it.

The peptic cell is an unlikely source of lysozyme in view of the diminished titers observed after the administration of intravenous insulin which exerts a powerful stimulant effect on pepsin production. The low lysozyme values following histamine stimulation provide additional evidence against peptic cell production of lysozyme, since histamine "washes out" the products of the peptic cells and may stimulate them somewhat as well (6).

The striking increase in the mucoprotein fraction of the gastric juice after histamine stimulation offers confirmatory evidence that this fraction has its origin in the mucus cells of the gastric gland (Figure 1). Histamine probably directly stimulates mucoprotein secretion and in addition may wash out the preformed mucoprotein from the mucoid neck cells of the gastric gland (6). The surface epithelial cells apparently do not respond to histamine stimulation. The mucoproteose fraction is thus relatively diminished, since the total dissolved mucin content of human gastric juice declines after histamine stimulation (Table III).

The concomitant fall in lysozyme with the mucoproteose fraction following histamine stimulation and the close relationship between the mucoproteose fraction and the lysozyme titer both before and after histamine stimulation offer good evidence that the surface epithelial cell is the site of origin of gastric lysozyme. This close parallelism might be anticipated from Glass's theory that the dissolved gastric mucoproteose is in part derived from the surface epithelium mucus by the digestive action of mucolytic enzymes (3).

The inverse relationship of the mucoprotein content to the lysozyme titer is additional evidence that the mucoid cell of the neck of the gland is not the source of lysozyme. Insulin, moreover, which greatly stimulates the production of this fraction, is associated with a decrease in lysozyme titer. Further evidence that the gastric gland does not secrete lysozyme is the failure of parasympathomimetic drugs and sympathectomy to alter the gastric lysozyme titer in any way ( 7$)$.

Finally, patients with pernicious anemia with extensive atrophy of the gastric glandular apparatus, as evidenced by a complete absence of acid and pepsin, secreted a normal amount of gastric lysozyme (Table IV). The mucoprotein fraction originating in the gastric gland was greatly diminished or absent while the mucoproteose fraction produced by the surface epithelial cells was increased significantly. This indicates again that gastric lysozyme has its origin in the surface epithelial cells of the gastric mucosa (Figure 1). 


\section{SUMMARY}

1. The administration of histamine to normal subjects and patients with peptic ulcer resulted in a profound fall in the concentration and total output of lysozyme in the gastric juice.

2. A significant decrease in the total output of lysozyme was observed in the gastric juice following the intravenous administration of insulin.

3. The mucoprotein fraction of the gastric juice, believed to be derived from the mucoid cells of the gastric gland, was increased by $196-334 \%$ following histamine stimulation.

4. The mucoproteose fraction of the gastric juice, originating in the surface epithelial cells, was diminished after the administration of histamine.

5. A direct relationship was observed between the concentration of mucoproteose fraction and the lysozyme content of the gastric juice.

6. The gastric juice lysozyme varied inversely with the mucoprotein fraction.

7. The gastric juice of seven patients with pernicious anemia contained a normal lysozyme content with an increased mucoproteose fraction and decreased or absent mucoprotein. Complete absence of acid and pepsin reflected the extensive glandular atrophy of the stomach in these patients.

8. These studies indicate that the surface epithelial cells are the source of gastric lysozyme, and that the parietal, peptic, and mucoid neck cells of the gastric gland do not participate in its production.

\section{ACKNOWLEDGMENT}

The authors gratefully acknowledge the cooperation of Dr. William P. Murphy during the course of these studies. The following rendered valuable technical assistance: Mrs. Kathryn Alex, Miss Marion Wagner, and Miss Barbara Johnson.

\section{BIBLIOGRAPHY}

1. Meyer, K., Prudden, J.'F., Lehman, W. L., and Steinberg, A., Lysozyme activity in ulcerative alimentary disease; lysozyme in peptic ulcer. Am. J. Med., 1948, 5, 482.

2. Reifenstein, R. W., Spiro, H. M., Young, J. C. G., Connolly, E. P., and Gray, S. J., The relationship of lysozyme to other components of gastric secretion in peptic ulcer. Gastroenterology, 1950, 16, 387.

3. Glass, G. B. J., and Boyd, L. J., The three main components of the human gastric mucin: dissolved mucoproteose, dissolved mucoprotein, and mucoid of the gastric visible mucus. I. Differentiation; some physical and chemical characteristics; classification. II. Method for separation and quantitative determination of each mucous component of the gastric content. III. Preliminary data on physiological and clinical significance of separate quantitative determination of the dissolved mucoproteose and dissolved mucoprotein in the gastric juice of man. Gastroenterology, 1949, 12, 821; 835; and 849.

4. Meyer, K., and Hahnel, E., The estimation of lysozyme by a viscosimetric method. J. Biol. Chem., 1946, 163, 723.

5a. Bucher, G. R., Grossman, M. I., and Ivy, A. C., A pepsin method: the role of dilution in the determination of peptic activity. Gastroenterology, 1945, 5, 501 .

b. Anson, M. L., and Mirsky, A. E., The estimation of pepsin with hemoglobin. J. Gen. Physiol., 1932, 16, 59.

c. Anson, M. L., The estimation of pepsin, trypsin, papain, and cathepsin with hemoglobin. J. Gen. Physiol., 1938-39, 22, 79.

d. Anson, M. L., in Northrop, J. H., Crystalline Enzymes. Columbia Univ. Press, New York, 1948, 2nd edition.

6. Babkin, B. P., Secretory Mechanism of the Digestive Glands. Hoeber, New York, 1950, 2nd edition.

7. Prudden, J. F., and Lane, N., Studies on the mechanism of alimentary lysozyme production; the absence of parasympathetic and histamine control. Gastroenterology, 1950, 15, 104. 